\title{
DAMPAK COVID-19 TERHADAP ISU KEPENDUDUKAN DI INDONESIA
}

\author{
Edwardus Iwantri Goma \\ Program Studi Pendidikan Geografi, Fakultas Keguruan dan Ilmu Pendidikan, Universitas Mulawarman, Samarinda, Indonesia \\ Email Koresponden: edgoma27@gmail.com
}

Diterima: 16-02-2021, Revisi: 20-05-2021, Disetujui: 07-06-2021

(C)2021 Program Studi Pendidikan Geografi, FISE, Universitas Hamzanwadi

\begin{abstract}
Abstrak Kematian, kemiskinan dan pengangguran merupakan dampak yang paling nyata dari pandemi Covid19 yang bisa ditemukan di kehidupan masyarakat Indonesia. Kajian ini bertujuan untuk menganalisis dampak pandemi Covid-19 terhadap isu kependudukan di Indonesia. Metode yang digunakan adalah metode deskriptif kualitatif berbasis kajian kepustakaan, dengan memanfaatkan data sekunder dari berbagai sumber. Adapun data yang dikumpulkan adalah data pengangguran dan kemiskinan dalam kurun waktu 2015 sampai 2020, data kematian akibat pandemi Covid-19 dari Maret 2019 sampai 13 Febaruari 2021. Teknik pengumpulan data dilakukan dengan menggunakan teknik dokumentasi yang dilakukan dalam tiga tahap yaitu 1) Editing; 2) Organizing; dan 3) Finding: Teknik analisis data yang digunakan dalam penelitian ini adalah dengan menggunakan metode analisis data model Miles dan Huberman yang dilakukan dalam tiga tahap yaitu 1) Reduksi data (data reduction); 2) Display data dan; 3) Gambaran kesimpulan. Hasil penelitian menunjukkan: 1) Rata-rata Angka kematian akibat Pandemi Covid-19 di Indonesia sebesar 0, 34 per 100.000 populasi. 2) Peningkatan persentase penduduk miskin dari 9, 22 persen pada September 2019 naik menjadi 9,78 pada Maret 2020, 3) Pengangguran naik 2,67 juta orang.
\end{abstract}

Kata kunci: Covid-19, kependudukan, kemiskinan, kematian, pengangguran

\begin{abstract}
Death, poverty and unemployment are the most tangible impacts of the Covid-19 pandemic that can be found in the lives of Indonesian people. This study aims to analyze the impact of the Covid-19 pandemic on population issues in Indonesia. The method used is descriptive qualitative method based on literature review, by utilizing secondary data from various sources. The data collected is data on unemployment and poverty in the period 2015 to 2020, data on deaths due to the Covid-19 pandemic from March 2019 to February 13, 2021. Data collection techniques are carried out using documentation techniques carried out in three stages, namely 1) Editing; 2) Organizing; and 3) Finding: The data analysis technique used in this research is using the data analysis method of the Miles and Huberman model which is carried out in three stages, namely 1) Data reduction; 2) Display data and; 3) Drawing conclusions. The results of the study show: 1) The average death rate due to the Covid-19 pandemic in Indonesia is 0.34 per 100,000 population. 2) An increase in the percentage of poor people from 9.22 percent in September 2019 to 9.78 in March 2020,3) Unemployment rose by 2.67 million people.
\end{abstract}

Keywords: Covid-19, population, poverty, death, unemployment

\section{PENDAHULUAN}

Pandemi Covid-19 dalam kurun waktu satu tahun terakhir telah menjadi pusat perhatian seluruh mayarakat internasional. Dalam periode waktu tersebut pandemi Covid-19 selalu menghantui kehidupan masyarakat internasional. Berbagai aspek kehidupan manusia pun terkena imbas dari pandemi Covid 19. Pasar ikan Wuhan, Cina pada Desember 2019 merupakan awal mula Covid-19 ditemukan. Pada waktu itu ditemukan lima pasien yang dirawat dengan Acute Respiratory Distress Syndrome (ARDS) pada periode 18 hingga 29 Desember 2019. Pada 31 Desember 2019 hingga 3 Januari 2020 angka ini meningkat menjadi 44 pasien. Kemudian dalam tempo yang singkat dan cepat Covid-19 sudah menyebar ke beberapa negara seperti Korea Selatan, Thailand, dan Jepang (Susilo et al., 2020). 
Flu dan MERS merupakan beberapa jenis penyakit yang bisa disebabkan karena virus Corona dan ditularkan dari hewan ke manusia. Sedangkan untuk Covid-19 masih belum jelas bagaimana penularannya, diduga dari hewan ke manusia karena kasus-kasus yang muncul di Wuhan semuanya mempunyai riwayat kontak dengan pasar hewan Huanan (kemkes.go.id, 2020). Per 13 Februari 2021 sudah 107.984.091 orang penduduk dunia yang terinfeksi Covid-19 dan sudah menjangkau ke 233 negara di dunia (covid19.go.id, 2021). Penyebarannya yang cepat dan dan massif membuat WHO pada 11 Maret 2020 meningkatkan status Covid-19 sebagai sebuah pandemi. Pandemi merujuk pada sebuah wabah suatu penyakit yang menyerang banyak korban, dan serempak di berbagai negara.

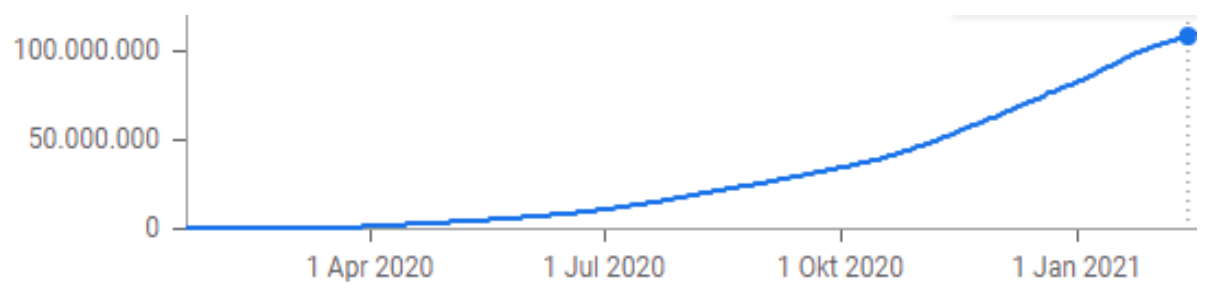

Gambar 1 Perkembangan Akumulasi Jumlah Pasien Terkonfirmasi Positif Covid-19 di Dunia (Sumber: news.google.com, 2021)

Penyebaran Covid-19 juga telah menjangkau Indonesia, dimana pada 02 Maret 2020 Presiden Republik Indonesia mengumumkan pasien pertama di Indonesia yang terkonfirmasi positif Covid-19. Kemudian per tanggal 13 Februari 2021 sudah 1.191 .990 penduduk Indonesia yang terkonfirmasi positif Covid-19 (covid19.go.id, 2021). Beberapa kebijakan pemerintah Indonesia sebagai upaya menekan laju penyebaran Covid-19 di Indonesia, antara lain: 1) Pembentukan Komite Penanganan Covid-19 dan Pemulihan Ekonomi Nasional yang bertugas untuk menyusun, merekomendasi, menigintegrasikan dan mengevaluasi berbagai kebijakan strategis pemerintah dalam upaya percepatan penanganan Covid-19 dan pemulihan ekonomi nasional (setkab.go.id, 2020); 2) pemerintah Indonesia menghentikan seluruh penerbangan dari Cina ke Indonesia dan menutup semua kunjungan dan transit warga negara asing di Indonesia (kependudukan.lipi.go.id, 2020); 3) pemerintah mengeluarkan kebijakan pelarangan mudik bagi perantau di berbagai daerah ke daerah asal mereka. Larangan mudik ini awalnya hanya ditujukan kepada Aparatur Sipil Negara (ASN) melalui edaran Menteri PANRB No 46/2020, larangan mudik ini pada akhirnya berlaku bagi seluruh penduduk Indonesia sebagaimana tertuang dalam Peraturan Menteri Perhubungan Republik Indonesia No. 25 tahun 2020.

Berbagai kebijakan yang diambil pemerintah tersebut nyatanya belum mampu menekan laju pertumbuhan dan penyebaran Covid-19 di Indonesia. Hal ini kemudian melendasari pemerintah mengambil kebijakan Pembatasan Sosial Berskala Besar (PSBB) sebagaimana tertuang dalam Peraturan Menteri Kesehatan Republik Indonesia Nomor 9 Tahun 2020 Tentang Pedoman Pembatasan Sosial Berskala Besar dalam Rangka Percepatan Penanganan Covid-19. Kebijakan PSBB tersebut diterapkan di beberapa Provinsi di Indonesia yang memiliki angka kasus positif Covid-19 yang cukup tinggi. Kebijakan PSBB ini diambil pemerintah sebagai upaya memutus mata rantai penularan Covid-19 di Indonesia.

Pandemi Covid-19 di Indonesia berdampak langsung terhadap berbagai bidang kehidupan masyarakat seperti menigkatnya angka pengangguran, angka kemiskinan dan angka kematian. Menurut Suryahadi et al., (2020), berbagai kebijakan dilakukan dalam rangka mengatasi penyebaran atau upaya memutus rantai penyebaran Covid-19. Keberlangsungan Covid-19 mengakibatkan banyak kegiatan ekonomi yang mengalami kontraksi bahkan terhenti berproduksi. Hal ini menimbulkan terjadinya peningkatan pengangguran, penurunan tingkat produktivitas individu maupun perusahaan, dan mendorong munculnya orang miskin baru yang secara agregat meningkatkan jumlah penduduk miskin. Hasil Suryahadi et al., (2020) menjadi kenyataan dimana per 20 April 2020 Kementerian Ketenagakerjaan mencatat, terdapat 116.370 perusahaan sektor formal dan sektor informal dengan Jumlah tenaga kerja 2.084.593 orang yang di PHK ataupn dirumahkan akibat Covid-19 (Livana et al., 2020). Angka kemiskinan di Indonesia juga semakin meningkat selama masa pandemi Covid-19, selama 
periode September 2019 sampai Maret 2020 saja tejadi penambahan jumlah penduduk miskin sebesar 1,5 juta jiwa (Tarigan et al., 2020). Tingkat mortalitas akibat Covid-19 juga mengalami peningkatan.

Pemerintah Indonesia sendiri tidak menutup mata terhadap dampak yang ditimbulkan akibat pandemi Covid-19 terhadap kehidupan masayarakat. Pemerintah Indonesia berupaya meringankan beban masyarakat yang tedampak pandemi Covid-19. Kebijakan listrik gratis 450 VA dan subsidi 900 VA, bantuan listrik untuk UMKM dan industri kecil, Kartu Prakerja, Bantuan Sosial Tunai (BST), bantuan karyawan swasta, dan beberapa kebijakan yang lainnya yang diambil pemerintah merupakan upaya pemerintah Indonesia mengurangi beban masyarakat yang terdampak pandemi Covid-19. Berdasarkan fakta tersebut penulis berusaha mengkaji dampak Covid-19 terhadap isu kependudukan di Indonesia. Isu kependudukan yang dikaji antara lain kematian, pengangguran dan Kemiskinan. Pada artikel ini penulis akan memaparkan fenomena pengangguran, kemiskinan, dan kematian yang mengalami peningkatan selama masa pandemi Covid-19 di Indonesia. Penulis menjelaskan angka pengangguran, kemiskinan, dan kematian di Indonesia selama pandemi Covid-19 di Indonesia.

\section{METODE PENELITIAN}

Metode yang digunakan dalam artikel ini adalah metode deskriptif kualtitatif berbasis kajian kepustakaan. Mengumpulkan data pustaka, membaca, mencatat, dan kemudian mengolahnya merupakan langkah-langkah dalam kajian kepustakaan. Sedangkan menurut Hadi (dalam Goma, 2019) studi kepustakan merupakan kegiatan mengumpulkan data penelitian yang berasal dari perpustakaan untuk menyelesaikan suatu penelitan. Pada penelitian ini jenis data yang digunakan adalah data sekunder yang diperoleh dari bebagai literatur yang relevan. Adapun data yang dikumpulkan adalah data tentang angka pengangguran, kemiskinan dan kematian di Indonesia. Data pengangguran dan kemiskinan menggunakan data dalam kurun waktu 2015 sampai 2020. Sedangkan data kematian menggunakan data angka kematian akibat pandemic Covid-19 dari Maret 2019 sampai 13 Febaruari 2021.

Teknik pengmpulan data dilakukan dengan menggunakan teknik dokumentasi yang dilakukan dalam tiga tahap yaitu: 1) Editing, pemeriksaan kembali data yang diperoleh terutama dari segi kelengkapan, kejelasan makna dan keselarasan makna antara yang satu dengan yang lain; 2) Organizing, mengorganisir data yang diperoleh dengan kerangka yang sudah diperlukan; 3) Finding, melakukan analisis lanjutan terhadap hasil pengorganisasian data dengan menggunakan kaidah-kaidah, teori dan metode yang telah ditentukan sehingga ditemukan kesimpulan yang merupakan hasil jawaban dari rumusan masalah. Teknik analisis data yang digunakan dalam penelitian ini adalah dengan menggunakan metode analisis data model Miles dan Huberman yang dilakukan dalam tiga tahap yaitu 1) Reduksi data (data reduction), pada tahap awal ini melakukan pemilihan, pemfokusan, penyederhanaan, abstraksi dan pentransformasian data mentah dalam catatan-catatan tertulis. Tujuannya untuk menda-patkan temuantemuan yang kemudian menjadi fokus dalam penelitian tersebut; 2) Display data, tahap ini data yang sudah direduksi kemudian didisplay hingga memberikan pemahaman terhadap data tersebut agar bisa menentukan langkah selanjutnya; 3) Gambaran kesimpulan, setelah reduksi dan display data terlaksana, maka dilakukan konklusi atau penarikan kesimpulan dari data yang telah diteliti (Sari \& Asmendri, 2020).

\section{TEMUAN DAN PEMBAHASAN \\ Fenomena Covid-19}

Corona virus merupakan salah satu kelompok virus yang bisa mengakibatkan infkesi pada saluran pernafasan manusia, mulai dari gangguan ringan hingga gangguan pernafasan berat. Para peneliti di Institute of Virology di Wuhan mengidentifikasi virus corona baru sebagai etiologi potensial dan menyebutnya novel coronavirus 2019 (nCoV-2019). Selanjutnya, Pusat Pengendalian dan Pencegahan Penyakit USA (CDC) menyebut virus corona sebagai 2019 novel coronavirus (2019-nCoV) dan sekarang penyakitnya populer dengan istilah coronavirus disease-19 (Covid-19) (Parwanto, 2020). Pada 11 Februari 2020, World Health Organization (WHO) mengumumkan nama penyakit ini sebagai Virus Corona Disease (Covid-19) yang disebabkan oleh virus SARS-CoV-2, yang sebelumnya disebut 2019-nCoV, (Susilo et al., 2020 dalam Fitriani, 2020). 
Saat ini, penyebaran Covid-19 dari manusia ke manusia menjadi sumber transmisi utama sehingga penyebaran menjadi lebih agresif. Transmisi Covid-19 terjadi melalui droplet yang keluar saat batuk atau bersin. Selain itu, telah diteliti bahwa Covid-19 dapat viabel pada aerosol (dihasilkan melalui nebulizer) selama setidaknya 3 jam (Susilo et al., 2020). Pada 12 Maret 2020 World Health Organization (WHO) menetapkan Covid-19 sebagai pandemi. WHO menetapkan penyakit ini sebagai pandemi karena seluruh warga dunia berpotensi terkena infeksi penyakit Covid-19.

Tanda dan gejala umum infeksi Covid-19 antara lain gejala gangguan pernapasan akut seperti demam, batuk dan sesak napas. Masa inkubasi rata-rata 5-6 hari dengan masa inkubasi terpanjang 14 hari. Pada kasus Covid-19 yang berat dapat menyebabkan pneumonia, sindrom pernapasan akut, gagal ginjal, dan bahkan kematian. Tanda-tanda dan gejala klinis yang dilaporkan pada sebagian besar kasus adalah demam, dengan beberapa kasus mengalami kesulitan bernapas, dan hasil rontgen menunjukkan infiltrat pneumonia luas di kedua paru. Sedangkan orang yang paling berisiko tertular penyakit ini adalah orang yang kontak erat dengan pasien Covid-19 termasuk yang merawat pasien Covid-19. Rekomendasi standar untuk mencegah penyebaran infeksi adalah melalui cuci tangan secara teratur, menerapkan etika batuk dan bersin, menghindari kontak secara langsung dengan ternak dan hewan liar serta menghindari kontak dekat dengan siapa pun yang menunjukkan gejala penyakit pernapasan seperti batuk dan bersin. Selain itu, menerapkan Pencegahan dan Pengendalian Infeksi (PPI) saat berada di fasilitas kesehatan terutama unit gawat darurat (Kementrian Kesehatan RI, 2020).

\section{Perkembangan Kasus Terkonfirmasi Positif Covid-19 di Indonesia}

Secara global Penambahan jumlah kasus Covid-19 berlangsung cukup cepat dan telah menyebar hampir ke seluruh belahan dunia. Per 13 Februari 2021 sudah 108,7 juta orang di seluruh dunia terinfeksi Covid-19 dan menjangkau ke 233 negara di dunia. Sejak ditemukan kasus Covid-19 di Indonesia, jumlah penderita Covid-19 mengalami peningkatan yang cukup tinggi. Per 13 februari 2021 sudah 1.191.990 penduduk Indonesia yang terkonfirmasi positif Covid-19 (covid19.go.id, 2021). Data tersebut menempatkan Indonesia pada peringkat ke-19 dengan jumlah pasien terkonfirmasi positif Covid-19 terbanyak di seluruh dunia (covid19.who.int, 2021). Berikut adalah gambar perkembangan jumlah pasien terkonfirmasi positif per 13 Februari 2021.

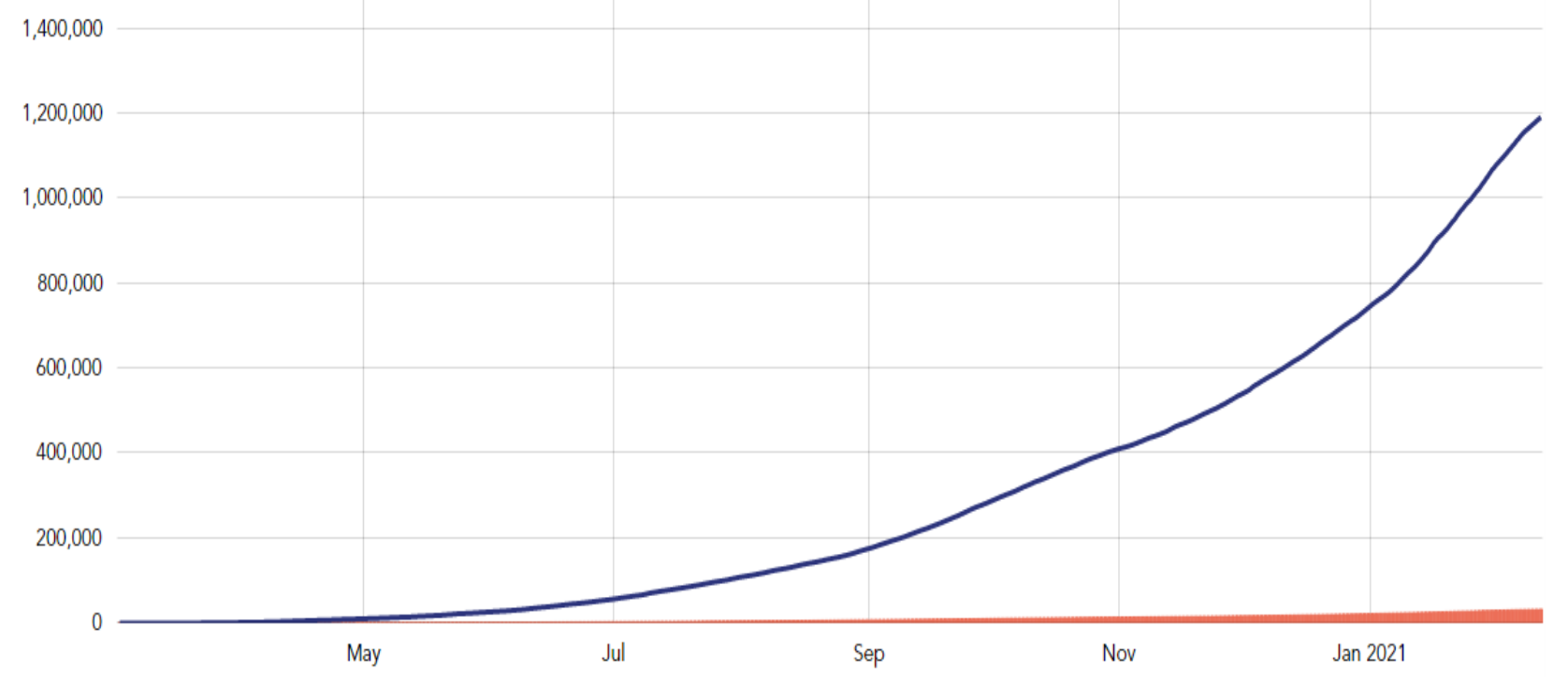

Gambar 2. Perkembangan Akumulasi Jumlah Pasien Terkonfirmasi Positif Covid-19 di Indonesia (Sumber: covid19.go.id, 2021)

Awal 2021 terjadi lonjakan yang cukup signifikan terhadap pertumbuhan kasus harian positif Covid-19 di Indonesia. Pada 03 Desember 2020 terdapat penambahan 8.369 pasien terkonfirmasi positif Covid-19, dan menjadi rekor tertinggi sepanjang 2020. Memasuki 2021 pertumbuhan terkonfirmasi positif Covid-19 per hari di Indonesia cenderung mengalami peningkatan yang cukup berarti. Pada 16 januari 2021 terdapat penambahan 14.224 pasien terkonfirmasi positif Covid-19 dan 
pada Pada 30 januari 2021 terdapat penambahan 14.518 pasien terkonfirmasi positif Covid-19. Angka ini menjadi rekor tertinggi sejak ditemukannya pasien postif covid-19 pertama kali di Indoensia sampai dengan saat ini (13 Februari 2020) (covid19.go.id,_2021). Berikut adalah gambar perkembangan kasus pasien terkonfirmasi positif per hari Covid-19 di Indonesia.

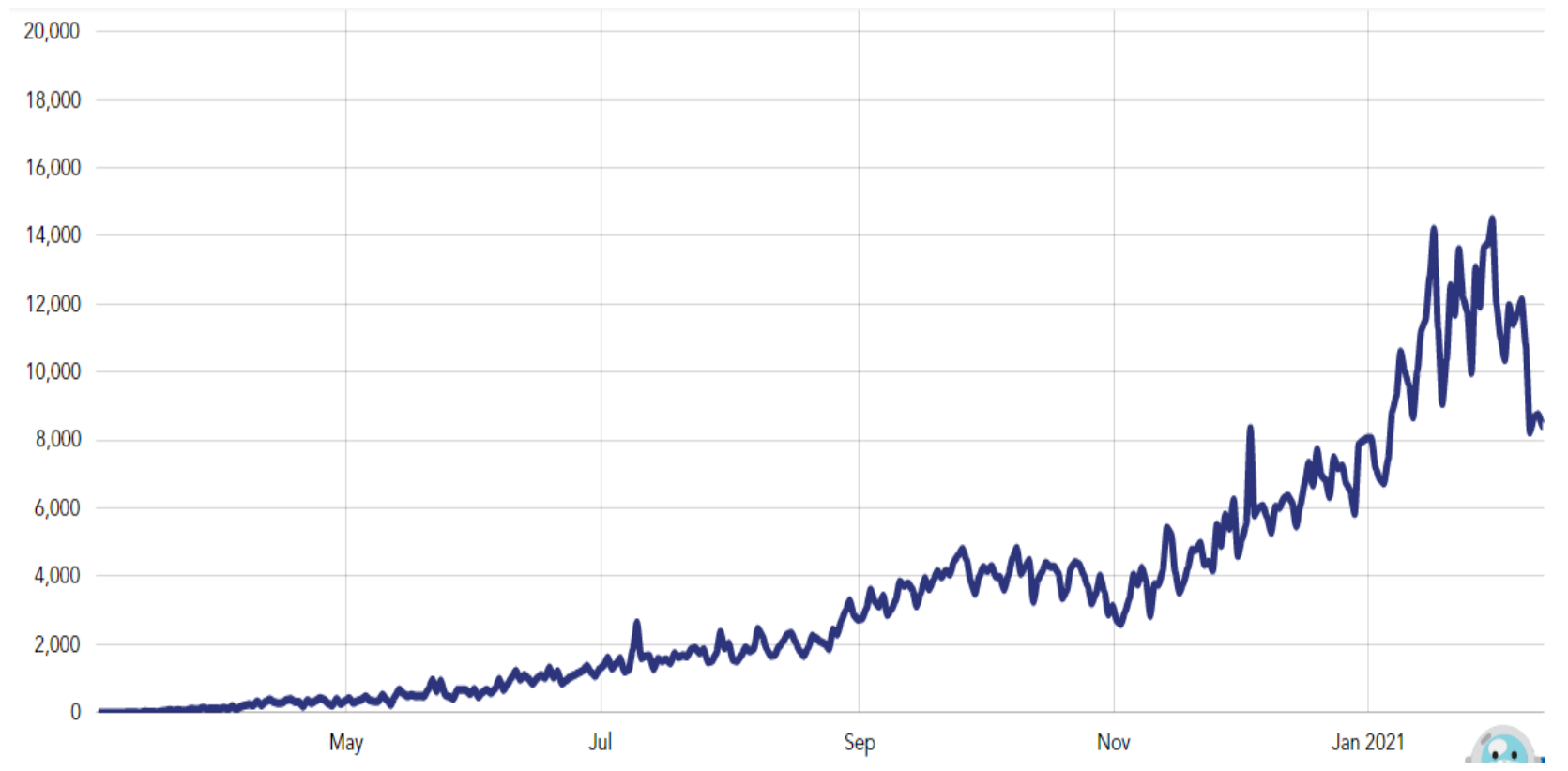

Gambar 3. Perkembangan Kasus Pasien Terkonfirmasi Positif Covid-19 di Indonesia per hari (Sumber: covid19.go.id, 2021)

\section{Kasus Kematian akibat Covid-19 di Indonesia}

Menurut Utomo (1985 dalam Alfana et al., 2017) kematian sebagai peristiwa hilangnya semua tanda-tanda kehidupan secara permanen, yang bisa terjadi setiap saat setelah kelahiran hidup. Sedangkan Menurut PBB dan WHO, kematian adalah hilangnya semua tanda-tanda kehidupan secara permanen yang bisa terjadi setiap saat setelah kelahiran hidup. Pada 18 Maret 2020 Indonesia untuk pertama kali melaporkan terjadinya kematian akibat Covid-19. Dimana terdapat 14 pasien terkonfirmasi positif Covid-19 yang meniggal. Dan sejak saat itu terjadi peningkatan yang cukup signifikan jumlah penderita Covid-19 di Indonesia yang meninggal dunia.

Menurut laporan WHO per 2 Desember 2020 bahwa tingkat kematian akibat Covid-19 di Indonesia lebih tinggi dibandingkan rata-rata dunia yakni sebesar 0,34 per 100.000 (3,4 \%). Sedangkan standar WHO rata-rata angka kematian global saat ini sebesar 2,39 persen (detik.com, 2020). Hal yang sama juga disampaikan Wiku Adisasmito selaku Juru Bicara, bahwa rata-rata kematian akibat Covid-19 di Indonesia sebesar 4,68 persen dan lebih dibandingkan rata-rata kematian global yang hanya sebesar 3,79 persen. Tren angka kematian di Indonesia juga cenderung mengalami Peningkatan. Pada Maret 2020 angka rata-rata kematian sebesar 4,69 persen, 8,54 persen pada April 2020, dan 6,68 persen pada Mei 2020 (cnnindonesia.com, 2020). Jadi tidak mengherankan angka kematian akibat Covid-19 di Indonesia menjadi yang tertinggi di Asia dan peringkat ke-17 di dunia (Sholikah \& Suni, 2021).

Puncak penambahan kasus kematian harian pasien terkonfirmasi positif Covid-19 di Indonesia terjadi pada awal 2021. Pada 28 Januari 2021 terdapat penambahan 476 pasien terkonfirmasi positif Covid-19 yang meinggal dunia, dan menjadi yang tertinggi sejak dilaporkan adanya pasien terkonfirmasi positi Covid-19 yang meniggal dunia (Gambar 3). Sehingga jika diakumulasikan per 13 Februari 2021, sudah 32.936 pasien terkonfirmasi positif Covid-19 yang meniggal dunia (Gambar 4). 


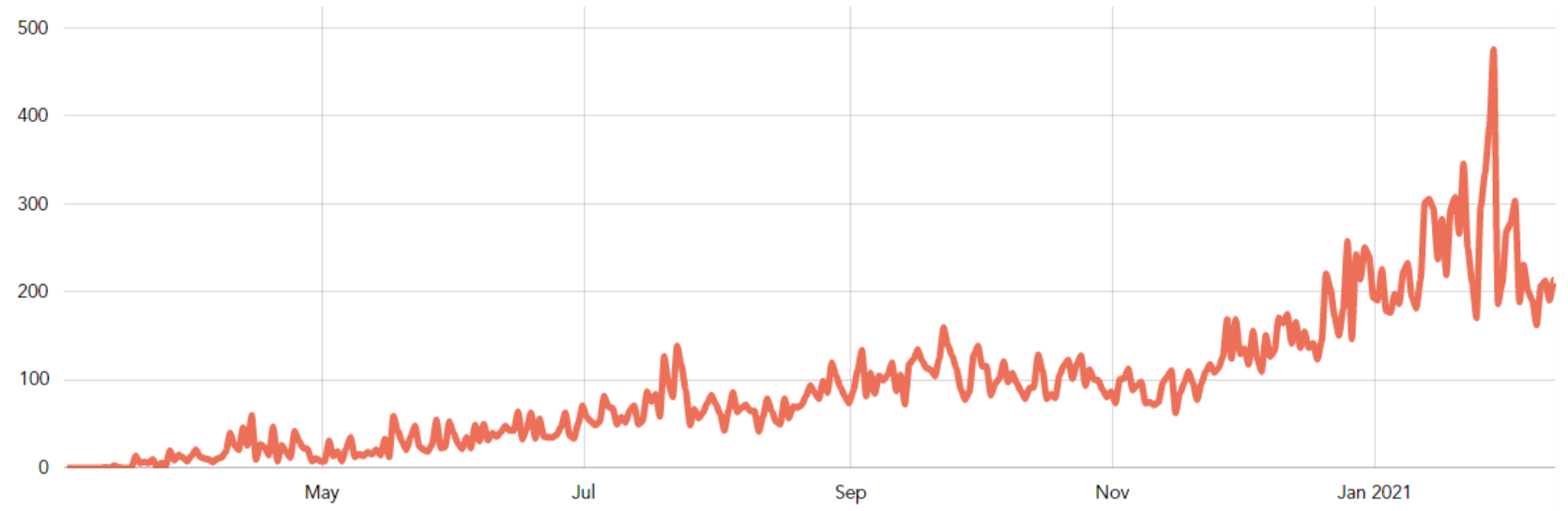

Gambar 4 Grafik Penambahan Kasus Kematian Harian Pasien Terkonfirmasi Positif Covid-19 di Indonesia (Sumber: covid19.go.id, 2021)

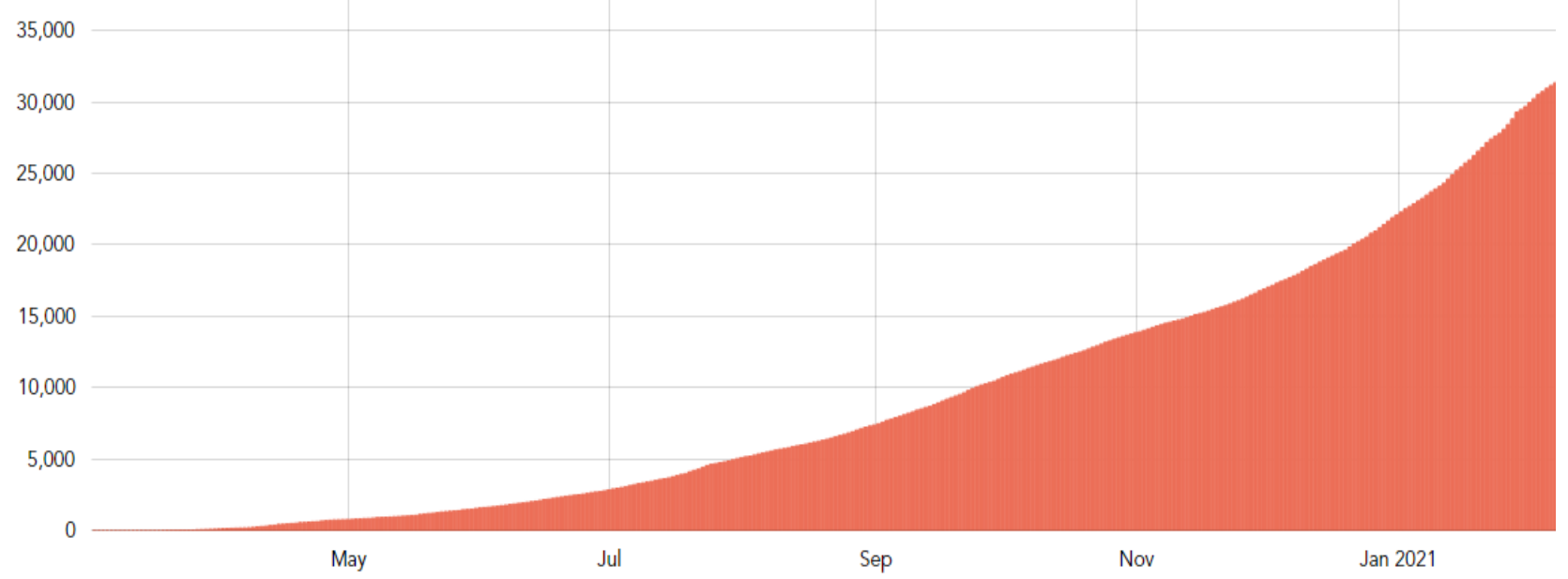

Gambar 5. Grafik Akumulasi kasus kematian Pasien Terkonfirmasi positif Covid-19 di Indonesia (covid19.go.id, 2021)

\section{Fenomena Kemiskinan akibat Covid-19 di Indonesia}

Fenomena kemiskinan di Indonesia bukan merupakan suatu fenomena yang baru. Kemiskinan memiliki banyak definisi, dan sebagian besar sering mengaitkan konsep kemiskinan dengan aspek ekonomi. Pertama, dari sudut pandang pengukuran, kemiskinan dibedakan menjadi dua yaitu kemiskinan absolut dan relatif. Kedua dari sudut pandang penyebab, kemiskinan dapat dikelompokkan menjadi kemiskinan alamiah dan struktural. Salah satu syarat penting agar suatu kebijakan pengentasan kemiskinan dapat tercapai maka harus ada kejelasan mengenai kriteria tentang siapa atau kelompok masyarakat mana yang masuk ke dalam kategori miskin dan menjadi sasaran program. Salain itu ada syarat yang juga harus dipenuhi yaitu harus dipahami secara tepat mengenai penyebab kemiskinan itu sendiri di masing-masing komunitas dan daerah/wilayah. Karena penyebab ini tidak lepas dari adanya pengaruh nilai-nilai lokal yang melingkupi kehidupan masyarakatnya (Nurwati, 2008). Sedangkan Badan Pusat Statistik (BPS) mendefinisikan kemiskinan di Indonesia sebagai kemampuan memenuhi kebutuhan dasar (basic needs approach). Dengan kata lain, kemiskinan merupakan ketidakmampuan dari sisi ekonomi untuk memenuhi kebutuhan dasar makanan dan bukan makanan yang diukur dari sisi pengeluaran. Jadi penduduk miskin merupakan penduduk pengeluaran perkapita yang memiliki rata-rata perbulan dibawah garis kemiskinan (bps.go.id, 2020).

World Bank memperkiakan sekitar 115 juta penduduk dunia akan masuk kategori kemiskinan ekstrem akibat Covid-19 pada 2020. Angka itu akan meningkat menjadi 150 juta orang pada 2021. Sebelum terjadi pandemi Covid-19 World Bank memprediksi kemiskinan ekstrim pada 2020 akan mengalami penurunan menjadi $7,9 \%$ pada 2020 . Kenyataannya kemiskinan justru mengalami peningkatan dan mempengaruhi antara sekitar 9,1\% sampai 9,4\% penduduk dunia (bbc.com, 2020). Tidak dapat dipungkiri bahwa pandemi Covid-19 mempengaruhi aspek kehidupan masyarakat Indonesia, salah satunya adalah kemiskinan. Angka kemiskinan di Indonesia Sebelum terjadi pendemi 
covid-19mengalami tren penurunan sejak tahun 2017 sampai akhir 2019. Namun pada awal 2020 kemiskinan di Indonesia justru mengalami tren peningkatan bersamaan dengan pandemi Covid-19 melanda Indonesia. Menurut prediksi The SMERU Research Institute akan ada peningkatan angka kemiskinan dari 9,2 persen pada September 2019 menjadi 9,7 persen pada akhir tahun 2020. Hal Ini berarti bahwa terdapat 1,3 juta lebih penduduk Indonesia akan jatuh ke dalam kemiskinan. Dalam proyeksi yang paling parah, angka kemiskinan akan meningkat menjadi 12,4 persen pada akhir 2020, yang berarti 8,5 juta lebih orang akan menjadi miskin (Suryahadi et al., 2020).

Fenomena yang sama juga ditemukan oleh BPS, dimana selama masa pandemi Covid-19 terjadi peningkatan angka persentase penduduk miskin di Indonesia. Pada September 2019 persentase penduduk miskin di Indonesia sebesar 9, 22 persen dan naik menjadi 9, 78 persen pada Maret 2020. Setara dengan penambahan 1,63 juta penduduk miskin sejak September 2017 (bps.go.id, 2020). Dilihat dari indikator kemiskinan berdasarkan persentase penduduk indonesia yang hidup di bawah garis kemiskinan diketahui bahwa sejak 2015 sampai 2019 persentase penduduk indonesia yang hidup di bawah garis kemiskinan mengalami tren penurunan. Namun memasuki tahun 2020 angka tersebut mengalami peningkatan (Gambar 5). Peningkatan persentase penduduk indonesia yang hidup di bawah garis kemiskinan selama tahun 2020 merupakan salah satu dampak dari Pandemi Covid-19 yang melanda Indonesia. Ditemukan pula fenomena bahwa semakin melebarnya gap kemiskinan di kota dan di desa, dimana penduduk miskin di kota lebih banyak dibandingkan di desa. Rasio gini naik dari 0,38 pada September 2019 menjadi 0,381 per Maret 2020. Fenomena ini mengindikasikan bahwa daerah kota merupakan awal mula pusat penyebaran Covid-19 (republika.id, 2020).

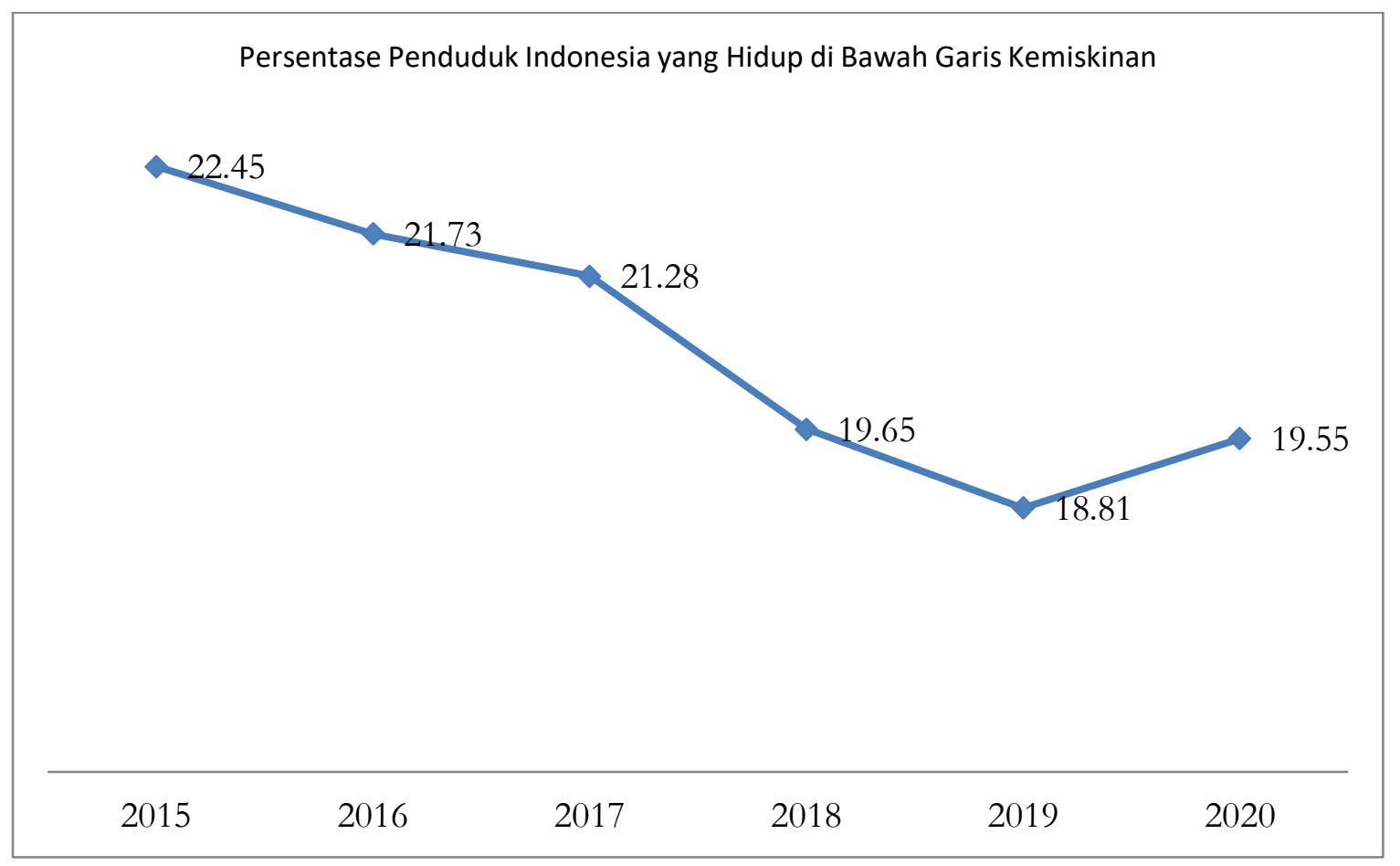

Gambar 6. Persentase Penduduk Indonesia yang Hidup di Bawah Garis Kemiskinan Tahun 2015-2020 (Sumber: bps.go.id, 2020)

\section{Fenomena Pengangguran akibat Covid-19 di Indonesia}

Pengangguran merupakan konsep yang merujuk pada orang yang tidak bekerja sama sekali, sedang mencari kerja, bekerja kurang dari dua hari selama seminggu, atau seseorang yang sedang berusaha mendapatkan pekerjaan yang layak. Menurut Sadono Sukirno (1994 dalam Franita, 2016), pengangguran adalah suatu keadaan dimana seseorang yang tergolong dalam angkatan kerja ingin mendapatkan pekerjaan tetapi belum dapat memperolehnya. Sedangkan Menurut Sukirno (2008 dalam Probosiwi, 2016) pengangguran merupakan seseorang yang sudah digolongkan dalam angkatan kerja yang secara aktif sedang mencari pekerjaan pada suatu tingkat upah tertentu, tetapi tidak dapat memperoleh pekerjaan yang diinginkan. Hal yang sama juga diungkapkan Murni (2006 dalam 
Probosiwi, 2016) bahwa pengangguran merupakan orang-orang yang usianya berada dalam usia angkatan kerja dan sedang mencari pekerjaan.

Selama masa pandemi Covid-19 Pemutusan Hubungan Kerja (PHK) menjadi sebuah fenomena yang lumrah terjadi. Pandemi Covid-19 berimbas pada banyaknya perusahaan yang dengan terpaksa melakukan PHK terhadap karyawannya. Menurut prediksi International Labour Organization (ILO) bahwa sekitar 25 juta pekerjaan di dunia akan hilang akibat pandemi Covid-19 (Ngadi et al., 2020). Fenomena yang sama juga terjadi di Indonesia, aspek ketenagakerjaan sangat terdampak akibat pandemi Covid-19. Tingkat Pengangguran Terbuka Indonesia sepanjang 2020 mengalami peningkatan yang cukup signifikan. BPS mencatat bahwa pada Agustus 2020 angka Tingkat Pengangguan Terbuka Indonesia menjadi yang tertinggi sejak 2015. Sejak 2015 sampai 2019 angka Tingkat Pengangguan Terbuka Indonesia sejatinya mengalami tren penurunan. Namun pada 2020 sejak pandemi Covid-19, angka Tingkat Pengangguan Terbuka Indonesia mengalami peningkatan yang cukup signifikan.

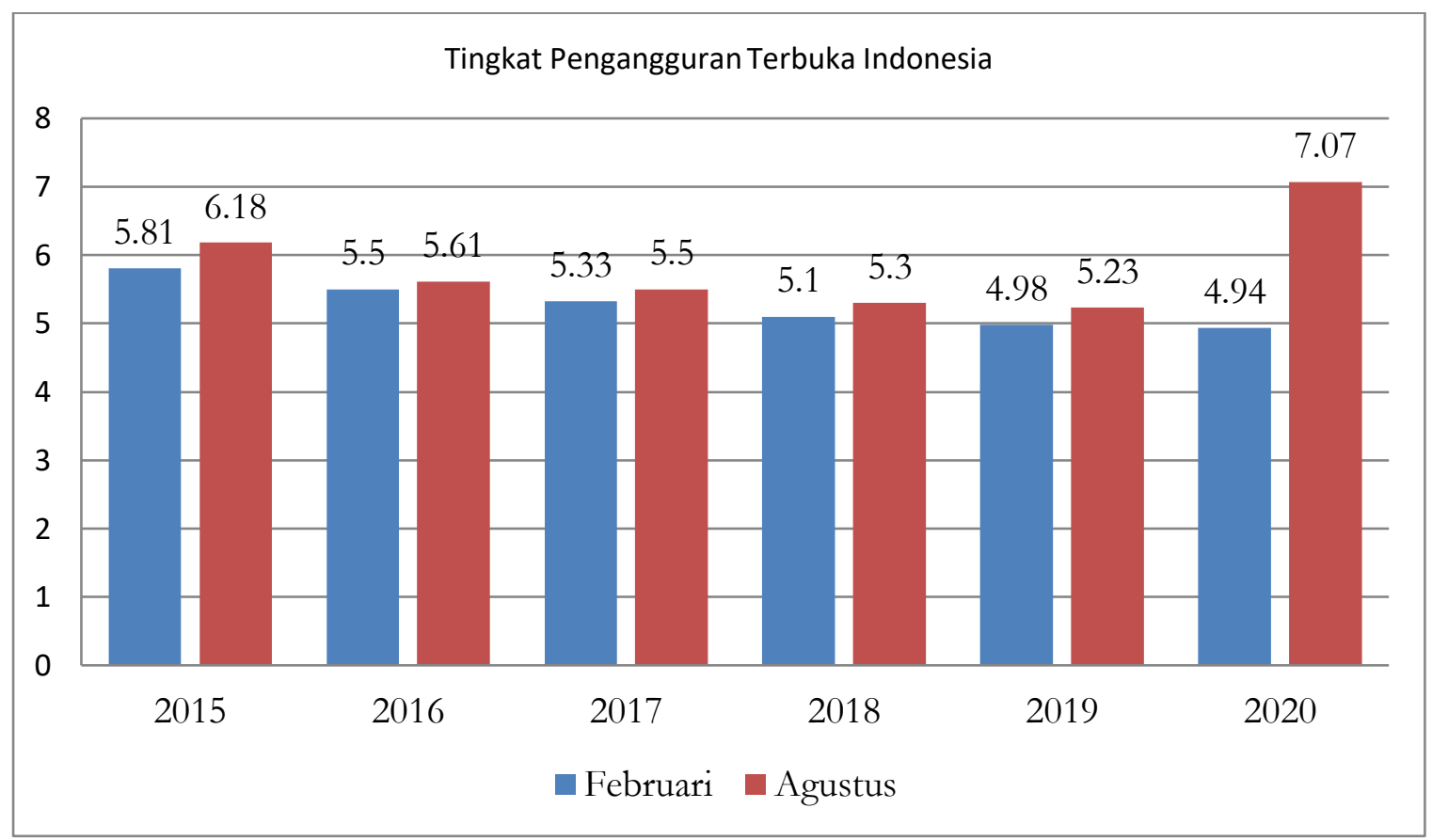

Gambar 7. Tingkat Pengangguran Terbuka Indonesia Tahun 2015-2020

(Sumber: bps.go.id, 2020)

Menurut hasil penelitian Lembaga Demografi Universitas Indonesia (LD-UI) ditemukan fakta bahwa terjadi penurunan pendapatan buruh/karyawan/pegawai sebesar 15, 6 persen dan terjadi pemutusan hubungan kerja (PHK) selama masa PSBB pada akhir April 2020 (Ngadi et al., 2020). Fenomena yang sama juga diungkapkan oleh Kemnaker, dimana selama pandemi Covid-19 terdapat 3,5 juta pekerja yang terkena PHK (sindonews.com, 2020). Sedangkan BPS mencatat bahwa terjadi peningkatan angka pengangguran dari 2,67 juta orang menjadi 9,77 juta orang hingga Agustus 2020. Dimana sebanyak 1,77 juta orang merupakan mereka yang tidak bekerja karena Covid-19, dan 24,03 juta orang mengalami pengurangan jam kerja karena Covid-19 (bps.go.id, 2020). Hal yang senada juga dikatakan Menko Perekonomian Airlangga Hartarto bahwa terjadi peningkatan yang signifikan jumlah pencari kerja maupun mereka yang sedang berstatus pengangguran di tengah pandemi Covid-19 dan mencapai 13 juta orang. Dari 13 juta orang tersebut, 3,5 juta merupakan mereka yang terdampak Covid-19 sehingga dirumahkan atau di-PHK (tirto.id, 2020).

\section{SIMPULAN}

Angka kematian akibat Covid-19 di Indonesia cukup tinggi jika dibandingkan dengan negaranegara yang lain, dimana Per 11 Februari 2021 angka kematian akibat Covid-19 di Indonesia sudah mencapai angka 32.381 orang. Menurut laporan WHO per 2 Desember 2020 bahwa tingkat kematian akibat Covid-19 di Indonesia lebih tinggi dibandingkan rata-rata dunia yakni sebesar 0,34 per 100.000 $(3,4 \%)$. Sedangkan standard WHO rata-rata angka kematian global saat ini sebesar 2,39 persen. Angka 
kematian akibat Covid-19 sebesar ini menempatkan Indonesia menempati posisi pertama di Asia dan peringkat ke-17 di dunia.

Pada isu kemiskinan, Pandemi Covid-19 di Indonesia juga berdampak pada peningkatan persentase penduduk miskin di Indonesia. Pada September 2019 persentase penduduk miskin di Indonesia sebesar 9, 22 persen dan naik menjadi 9, 78 persen pada Maret 2020. Setara dengan penambahan 1,63 juta penduduk miskin sejak September 2017. Berdasarkan persentase penduduk indonesia yang hidup di bawah garis kemiskinan didiapati bahwa sejak 2015 sampai 2019 persentase penduduk indonesia yang hidup di bawah garis kemiskinan mengalami tren penurunan. Namun memasuki tahun 2020 angka tersebut mengalami peningkatan.

Hal yang sama juga pada isu pengangguran, dimana pandemi Covid-19 berdampak pada peningkatan angka pengangguran di Indonesia, diamana terjadi penurunan pendapatan buruh/karyawan/pegawai sebesar 15, 6 persen dan terjadi pemutusan hubungan kerja (PHK) selama masa PSBB pada akhir April 2020. Hingga Agustus 2020 terjadi peningkatan jumlah pengangguran dari 2,67 juta orang menjadi 9,77 juta orang. Dimana sebanyak 1,77 juta orang merupakan mereka yang tidak bekerja karena Covid-19, dan 24,03 juta orang mengalami pengurangan jam kerja karena Covid19. Tingkat Pengangguan Terbuka Indonesia sepanjang 2020 mengalami peningkatan yang cukup signifikan. Sejak 2015 sampai 2019 angka Tingkat Pengangguan Terbuka Indonesia sejatinya mengalami tren penurunan. Namun pada 2020 sejak pandemi Covid-19, angka Tingkat Pengangguan Terbuka Indonesia mengalami peningkatan yang cukup signifikan.

\section{DAFTAR PUSTAKA}

Alfana, M. A. F., Iffani, M., \& Hanif, W. A. N. P. (2017). Mortalitas di Indonesia (Sejarah Masa Lalu dan Proyeksi ke Depan). Prosiding Seminar Nasional dan PIT IGI XVIII 2015.

bbc.com. (2020). Pandemi Covid-19 Sebabkan Kemiskinan Ekstrem di Selurub Dunia akan Melonjak untuk Pertama Kalinya Sejak Tabun 1998. Diakses pada 08 Febaruari 2021 dari https://www.bbc.com/indonesia/dunia-54453523.

bps.go.id, (2020). data covid-19. diakses pada 13 Februari 2021.

cnnindonesia.com. (2020). Kematian Covid di Indonesia Masib Lebih Tinggi dari Rata-rata Global. Diakses pada 08 Februari 2020, dari https://www.cnnindonesia.com/nasional/20200804173453-20532127/kematian-covid-di-indonesia-masih-lebih-dari-rata-rata-global.

covid19.go.id. (2021). Data dan peta sebaran Covid-19 di Indonesia. diakses pada 13 Febaruari 2021.

covid19.who.int. (2021). Data covid-19 Internasional. diakses pada 13 Februari 2021.

detik.com . (2020). WHO: Angka Kematian Covid-19 di Indonesia Lebih Tinggi dari Dunia. Diakses pada 08 Februari 2020 dari https://health.detik.com/berita-detikhealth/d-5282583/who-angka-kematiancovid-19-di-indonesia-lebih-tinggi-dari-dunia.

Fitriani, N. I. (2020). Tinjauan Pustaka Covid-19: Virologi, Patogenesis, dan Manifestasi Klinis. Jurnal Medika Malhayati 4(3), 194-201.

Franita, R. (2016). Analisa Pengangguran di Indonesia. Jurnal Ilmu Pengetahuan Sosial, 1, 88-93.

Goma, E. I. (2019). Situasi Keluarga Berencana di Provinsi Kalimantan Timur. Georafflesia, 4(2), $201-$ 210.

Kementrian Kesehatan RI. (2020). Pedomaan Pencegahan dan Pengendalian Corona Virus Disase (Covid-19). Jakarta: Kementrian Kesehatan RI.

kemkes, go.id. (2020). Perkembangan kasus Covid-19. diakses pada 27 Maret 2020.

Livana, P. H., Suwoso, R. H., Febrianto, T., Kushindarto, D., \& Aziz, F. (2020). Dampak Pandemi Covid-19 bagi Perekonomian Masyarakat Desa. Indonesian Journal of Nursing and Health Sciences, 1(1), $37-48$. 
Ngadi, N., Meliana, R., \& Purba, Y. A. (2020). Dampak Pandemi Covid-19 Terhadap PHK dan Pendapatan Pekerja di Indonesia. Jurnal Kependudukan Indonesia, 2902, 43.

Nurwati, N. (2008). Kemiskinan: Model Pengukuran, Permasalahan dan Alternatif Kebijakan. Jurnal Kependudukan Padjadjaran, 10(1), 245387.

Parwanto, M. (2020). Virus Corona (2019-nCoV) Penyebab COVID-19. Jurnal Biomedika dan Kesehatan, 13(8), 751-752.

Probosiwi, R. (2016). Pengangguran dan Pengaruhnya terhadap Tingkat Kemiskinan. Jurnal Penelitian Kesejabteraan Sosial, 15(02), 89-100.

republika.id. (2020). Covid-19 dan Kemiskinan. Diakses pada 13 Februari 2021, dari https://www.republika.id/posts/8615/covid-19-dan-kemiskinan.

Sari, M., \& Asmendri, A. (2020). Penelitian Kepustakaan (Library Research) dalam Penelitian Pendidikan IPA. Natural Science: Jurnal Penelitian Bidang IP A dan Pendidikan IP A, 6(1), 41-53.

setkab.go.id. (2020). Ini Tugas Komite Penanganan Covid-19 dan Pemulihan Ekonomi Nasional Sesuai Perepes 82 2020. Diakses pada 13 Februari 2021 dari https://setkab.go.id/ini-tugas-komite-penanganancovid-19-dan-pemulihan-ekonomi-nasional-sesuai-perpres-82-2020/.

Sholikah, N., \& Suni, P. (2021). Tingginya Kasus Aktif dan Angka Kematian Akibat Covid-19 di Indonesia. Info Singkat: Kajian Singkat Terhadap Isu Aktual Dan Strategis, XII(3).

sindonews.com. (2020). Memotong Rantai Kemiskinan dan Dampat Dari Pandemi Covid-19. Diakses pada 13 Februari 2021, dari https://ekbis.sindonews.com/read/221804/33/memotong-rantai-kemiskinandampak-dari-pandemi-covid-19-1604621479.

Suryahadi, A., Al Izzati, R., \& Suryadarma, D. (2020). The Impact of Covid-19 Outbreak on Poverty: An Estimation for Indonesia. Jakarta: The SMERU Research Institute.

Susilo, A.et al. (2020). Coronavirus Disease 2019 : Tinjauan Literatur Terkini Coronavirus Disease 2019 : Review of Current Literatures. 7(1), 45-67.

Tarigan, H., Juni H. Sinaga, \& Rachmawati, R. R. (2020). Dampak Pandemi Covid-19 terhadap Kemiskinan di Indonesia. Pusat Sosial Ekonomi dan Kebijakan Pertanian, 3, 457-479.

tirto.id. (2020). Dampak Pandemi Angka Pengangguran RI Diperkirakan 13 Juta Orang. Diakses pada 13 Februari 2021 dari https://tirto.id/dampak-pandemi-angka-pengangguran-ri-diperkirakan-13-jutaorang-f6do. 